\title{
Inhibitor of Nuclear Factor Kappa-B Kinase-Interacting Protein
}

National Cancer Institute

\section{Source}

National Cancer Institute. Inhibitor of Nuclear Factor Kappa-B Kinase-Interacting Protein.

NCl Thesaurus. Code C96382.

Inhibitor of nuclear factor kappa-B kinase-interacting protein (350 aa, $\sim 39 \mathrm{kDa}$ ) is

encoded by the human IKBIP gene. This protein plays a role in the induction of apoptosis. 